\title{
RESPONSE OF MICROBIAL ACTIVITY TO BIOTURBATION OF NEREID (PERINEREIS AIBUHITENSIS) IN INTERTIDAL MUDFLAT SEDIMENTS
}

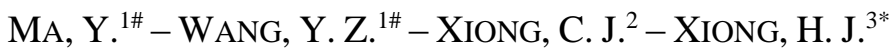 \\ ${ }^{I}$ Fisheries College of Jimei University, Engineering Research Center of the Modern Technology \\ for Eel Industry, Ministry of Education, Xiamen 361021, China \\ ${ }^{2}$ College of Foreign Language, Hunan University, Changsha 410006, China \\ ${ }^{3}$ College of Food and Biological Engineering, Jimei University, Xiamen 361021, China \\ ${ }^{\#}$ Ying Ma and Yongzhong Wang should be considered joint first authors. \\ ${ }^{*}$ Corresponding author \\ e-mail: hjxiong@jmu.edu.cn \\ (Received 21 $1^{\text {st }}$ May 2020; accepted $17^{\text {th }}$ Sep 2020)
}

\begin{abstract}
Although numerous studies have reported the effects of the nereid polychaete bioturbation on sediments, its effects on soil microbial activity remain poorly understood. For this study, nereids (Perinereis aibuhitensis) were introduced to intertidal mudflat sediments in a laboratory experiment, and the resulting bioturbation effects on soil microbial activity dynamics were investigated via the Biolog ECO method. The results reveal high microbial utilization of carbohydrates, amino acids, and polymers, while the utilization of carboxylic acids, amines, and miscellaneous contents was low. After introducing nereids, the physicochemical characteristics and heavy metal values did not significantly change; however, the sediment microbial activity and the carbon substrate utilization diversity increased significantly. Furthermore, in a specific sowing range, higher sowing density of nereids showed a higher enhancing effect on microbial activity and carbon substrate utilization diversity. Nereid bioturbation is therefore suggested to increase the microbial utilization of carbohydrates and amino acids, while it decreases the utilization of polymers.
\end{abstract}

Keywords: nereid polychaete, marine sediment, biological disturbance, bacteria, metabolic response, Biolog ECO

\section{Introduction}

The polychaete Perinereis aibuhitensis is a common invertebrate of the phylum Annelida and the family Nereidae. It is widely distributed along the coastal and estuarine regions of the Northwest Pacific (Tian et al., 2019), and plays a vitally important role in the coastal intertidal ecosystem due to its bioturbation activity. Bioturbation is the physical agitation, mixing and restructuring of sedimentary particles by benthic organisms. The bioturbation of burrowing, breathing, and feeding of nereids reworks the physical structure of the sediment, extends the contact area of bottom sediments with dissolved oxygen (Wenzhöfer et al., 2004), thus promoting the mineralization and decomposition of organic matter (Tsutsumi et al., 2005; Deng, 2006). The polychaete nereid also exhibits the ability of bioaccumulation and soluble binding of heavy metals (Berthet et al., 2003; Durou et al., 2005), and can enhance the release of buried hydrocarbons pollutants in sediments (Tian et al., 2019), thus helping to improve the benthic environment.

Macrobenthic bioremediation is largely implemented via influencing microorganisms within the sediments, and it is vital in illuminating microorganism variations during the 
bioturbation process. Previous studies have shown that macrobenthic bioturbation of burrowing imposed a selective pressure and exerted a functionally-conserved altering effect on sediment microbes even under different environmental conditions (Booth et al., 2019). Microbial communities within burrows are distinct from those at the sediment surface, and different burrow types of benthic animals incubate diverse bacterial taxa (Marinelli et al., 2002; Bertics and Ziebis, 2009; Pischedda et al., 2011). With the benthic bioturbation of feeding, burrowing and other activities, sediments were loosened and large grains became small, thus contributing to microorganism degradation and soil eutrophication alleviation (Sun et al., 2019). Macrobenthic bioturbation has also been reported to facilitate the bacteria-mediated nitrification and denitrification process (Banks et al., 2013), affect the release and distribution of polycyclic aromatic hydrocarbons (PAHs), and stimulate the development of hydrocarbon degrading bacteria, which may help the bioremediation process in oil-contaminated sediments (Cuny et al., 2007). Our previous studies reported that bioturbation of introduced macrobenthos increased the diversity of archaea and favored the development of ecologically important bacteria and archaea (Ma et al., 2015; Deng et al., 2015). However, studies about the influence of bioturbation on microbial activities have rarely been reported.

Community level physiological catabolic profiles (CLPPs) has been used as an important method for studying the microbial community structure of soil for many years (Garland and Mills, 1991; Murugan et al., 2014), and has been widely used for the assessment of microbial functional diversity in agricultural and forest soils under different administration process (Grayston et al., 1998; Islam et al., 2011; Chaudhry et al., 2012). In addition, estimating the soil microbial communities through $\mathrm{C}$ source use patterns has been proven to be a sensitive method for detecting variations caused by management practices (Gomez et al., 2006), and the test species has expanded from prokaryote bacteria to eukaryotic algae (Kim et al., 2017). Biolog GN and ECO microplates (Biolog, Inc.) were typically used in CLPPs analyses, while ECO plates, first described by Insam (1997), have more frequently been used in microbial ecology studies. The ECO-plate is composed of 96 wells and contains 31 different carbon sources and a blank, each carbon source and blank have 3 repeats; these carbon sources are regarded to be more relevant to the ecological functions of microorganisms perform in ecosystems (Choi and Dobbs, 1999; Loranger-Merciris et al., 2006). The Biolog ECO plate assay reflects the microbial metabolic diversity within the ecosystem via testing of a reduced number of ecologically relevant carbon sources (Nautiyal et al., 2010). In this study, a laboratory experiment was designed to simulate bioturbation of mudflat sediments using nereids, and Biolog ECO was utilized to investigate the influence of nereid bioturbation on microbial activities.

\section{Materials and methods}

\section{Experiment setup and sample collection}

Intertidal mudflat sediments were collected from Xiamen, Fujian province, China $\left(118^{\circ} 6^{\prime} 20^{\prime \prime} \mathrm{E}, 24^{\circ} 34^{\prime} 49^{\prime \prime} \mathrm{N}\right)$. After removing large particles and macrobenthos, the sediments were completely mixed and evenly divided into 12 plastic boxes (each with a dimension of about $42 \times 30 \times 19.2 \mathrm{~cm}$ ), and the weight of sediment deposed in each box was about $20 \mathrm{~kg}$. Polychaete nereids (Perinereis aibuhitensis) were bought from Fuqing, Fujian Province, and were temporally cultured in seawater at room temperature for three days. Active nereids with similar size were weighed and measured, and were selected for the ensuing experiment. Nereids were sowed in culture boxes in three different densities: 
10, 20, and 30 individuals per box, named as T10, T20, and T30, respectively. Each sowing density had three replicates. Furthermore, three boxes were designed as blank controls without nereids, and this control group was named C. To simulate daily tidal cycles, seawater was injected into the boxes at 8 am to cover the soil surface, and was released at $8 \mathrm{pm}$ each day of the experiment. The experiment started on October $1^{\text {st }}$ and ended on November $15^{\text {th }} 2014$ with a total duration of 45 days.

Sediment samples were collected from each culturing box at $0,3,7,14,21,28,35$, and 45 days after the sowing of nereids, and were used for Biolog ECO analysis. Detailed information for the samples is shown in Table 1.

Table 1. Samples collected in the laboratory bioremediation model

\begin{tabular}{|c|c|c|c|c|c|}
\hline \multirow{2}{*}{$\begin{array}{l}\text { Control group } \\
\text { without nereids }\end{array}$} & \multicolumn{3}{|c|}{ Treatment groups with nereids } & \multirow[b]{2}{*}{ Sampling date } & \multirow{2}{*}{$\begin{array}{c}\text { Interval after } \\
\text { sowing nereids (d) }\end{array}$} \\
\hline & \begin{tabular}{|c|}
10 individuals \\
per box
\end{tabular} & \begin{tabular}{|c|}
20 individuals \\
per box
\end{tabular} & \begin{tabular}{|c|}
30 individuals \\
per box
\end{tabular} & & \\
\hline C-Od & T10-0d & T20-0d & T30-0d & Oct. 1,2014 & Od \\
\hline$C-3 d$ & $\mathrm{~T} 10-3 \mathrm{~d}$ & T20-3d & T30-3d & Oct. 4, 2014 & $3 d$ \\
\hline $\mathrm{C}-7 \mathrm{~d}$ & $\mathrm{~T} 10-7 \mathrm{~d}$ & $\mathrm{~T} 20-7 \mathrm{~d}$ & $\mathrm{~T} 30-7 \mathrm{~d}$ & Oct. 8, 2014 & $7 \mathrm{~d}$ \\
\hline C-14d & $\mathrm{T} 10-14 \mathrm{~d}$ & $\mathrm{~T} 20-14 \mathrm{~d}$ & T30-14d & Oct. 15,2014 & $14 d$ \\
\hline C-21d & T10-21d & T20-21d & T30-21d & Oct. 22,2014 & $21 d$ \\
\hline$C-28 d$ & $\mathrm{~T} 10-28 \mathrm{~d}$ & T20-28d & T30-28d & Oct. 29, 2014 & $28 \mathrm{~d}$ \\
\hline$C-35 d$ & $\mathrm{~T} 10-35 \mathrm{~d}$ & $\mathrm{~T} 20-35 \mathrm{~d}$ & T30-35d & Nov. 5, 2014 & $35 d$ \\
\hline$C-45 d$ & $\mathrm{~T} 10-45 \mathrm{~d}$ & $\mathrm{~T} 20-45 \mathrm{~d}$ & $\mathrm{~T} 30-45 \mathrm{~d}$ & Nov. 15, 2014 & $45 \mathrm{~d}$ \\
\hline
\end{tabular}

\section{Determination of microbial activity in sediments}

Biolog ECO plates were utilized to determine the metabolic diversity of soil bacterial communities. About $5 \mathrm{~g}$ sediment were added to a $250 \mathrm{ml}$ conical flask with $45 \mathrm{ml}$ of $0.85 \%$ sterilized saline water, and were shaken for $1 \mathrm{~h}$ at $180 \mathrm{rpm}$ on a shaker; then, the mixture was left standing for $30 \mathrm{~min}$. The supernatant was diluted to $10^{-3}$ and $150 \mu \mathrm{L}$ of the dilution were inoculated in the well of the preheated Biolog ECO plate and incubated at $28{ }^{\circ} \mathrm{C}$ for seven days. The optical density $(\lambda=590 \mathrm{~nm})$ of each well was determined immediately $(0 \mathrm{~h})$ as well as every $24 \mathrm{~h}$.

Average well color development (AWCD) indicates the oxidizing capacity of sediment microorganisms, cultured in Biolog microplates and typically represents the overall metabolic capacity of microorganisms (Garland and Mill, 1991). $\mathrm{AWCD}=\Sigma(\mathrm{R}-\mathrm{C}) / 31$, where $\mathrm{R}$ is the optical density of every well with added carbon source, $\mathrm{C}$ is the absorbance value of the control well (without a carbon source), and 31 stands for 31 types of carbon sources. Data obtained at $96 \mathrm{~h}$ were used to calculate relative utilization ratios for different carbon sources and microbial metabolic diversity indices. The relative utilization ratio was determined via the percentage of AWCD of a certain carbon substrate in the total AWCD of all carbon substrates. The formulas used to calculate the Shannon-Wiener Diversity H', the Simpson index D, and the Pielou evenness index Jsw have been described earlier (Dobranic and Zak, 1999). Data were subjected to statistical analysis using Excel 2010 and SPSS 17.0, and were analyzed by one-way ANOVA among multiple groups or a Student's t-test between two groups. A value of $p<0.05$ was considered statistically significant. The principal component analysis (PCA) was performed with Canon software. 


\section{Results}

\section{Nereid growth and survival}

By the end of the experiment, all nereids were dug out from each culture box. Survival rate, body weight, and body length were assessed, and the resulting data are listed in Table 2. Nereid survival rate were higher than $80 \%$ for each treatment group, and in the culture box of ten individuals, the survival rate reached up to $100 \%$. Body weight and body length increased for all treatments, and the largest values were also detected in the culture box of ten individuals, indicating that a more diluted sowing density might be better for nereid growth. However, the differences among different groups were not significant $(P>0.05)$.

Table 2. Survival rate, body weight, and body length of nereid in a laboratory experiment

\begin{tabular}{|c|c|c|c|c|}
\hline & \multirow{2}{*}{$\begin{array}{l}\text { Before sowing } \\
\text { nereids }\end{array}$} & \multicolumn{3}{|c|}{45 days after sowing nereids } \\
\hline & & $\begin{array}{c}0 \text { individuals } \\
\text { /box }\end{array}$ & $\begin{array}{c}20 \text { individuals } \\
\text { /box }\end{array}$ & $\begin{array}{c}30 \text { individuals } \\
\text { /box }\end{array}$ \\
\hline Survival rate & & $100.0 \%$ & $80.0 \%$ & $85.6 \%$ \\
\hline Body weight \pm SD (g) & $1.76 \pm 0.35$ & $2.30 \pm 0.46$ & $2.06 \pm 0.49$ & $2.11 \pm 0.39$ \\
\hline Body length \pm SD $(\mathrm{cm})$ & $14.21 \pm 1.67$ & $15.58 \pm 1.01$ & $14.56 \pm 1.98$ & $14.91 \pm 2.38$ \\
\hline
\end{tabular}

Note: Data were obtained from three replicates. SD means standard deviation

\section{Overview of sediment microbial metabolic activity}

The AWCD values of samples that were collected at different times, determined after $96 \mathrm{~h}$ of incubation, which corresponds to the maximum growth time of microorganisms in the Biolog ECO plates, are shown in Fig. 1. The AWCD values of the control group (C) without nereids gradually decreased over the course of the experiment, indicating a decreasing trend of sediment microbial activity. The AWCD value of group T10 (with nereids at a density of 10 per box) also showed a decreasing trend, except for the value of the sample collected at day seven. The variations of AWCD curves of groups T20 and T30 (with sowing densities of 20 and 30 per box, respectively) were similar: the values increased at $7 \mathrm{~d}$ and $3 \mathrm{~d}$, respectively, followed by a decrease until $21 \mathrm{~d}$, and increasing again until the end of the experiment ( $45 \mathrm{~d})$. Most of the AWCD values of T20 and T30 were higher than those at the beginning of the experiment $(0 \mathrm{~d})$, indicating that the overall sediment microbial activities of groups T20 and T30 increased during experiment.

A comparison between samples collected at the same time revealed that all average AWCD values of treatment samples (except the value of T30-21d) were higher than those of control samples, and most of the differences reached significant levels $(P<0.05$, Table S1), suggesting that nereid bioturbation stimulated the overall microbial metabolic activity. Different nereid density exerted a different influence on microbial activity. The microbial activity value order of treatment samples changed severely before $21 \mathrm{~d}$ : on the third day after nereid sowing, the AWCD of T30 was significantly higher than in the other two treatments $(P<0.05$, Table $S 1)$; however, on the seventh day, T20 was maximal, and T10 became the highest on the $14^{\text {th }}$ and $21^{\text {st }}$ day, respectively, among all the samples collected at the same times. These results indicate that in the early stage of the experiment (before $7 \mathrm{~d}$ ), higher nereid density influenced the microbial activity more quickly, while in the mid stage of the experiment $(7 \mathrm{~d}-21 \mathrm{~d})$, the influence of a lower nereid density grew gradually. However, 21 days after nereid sowing, the influence of higher nereid 
density increased again, and the AWCD values of T20 and T30 were significantly higher than those of T10 after 28 days of nereid sowing $(P<0.05$, Table S1). In summary, the average AWCD value of T10 was lower than in other treatments, and the values of T20 and T30 were similar. These results indicate that in a certain sowing range, higher sowing density of nereids seemed to have a more enhancing effect on microbial activity.

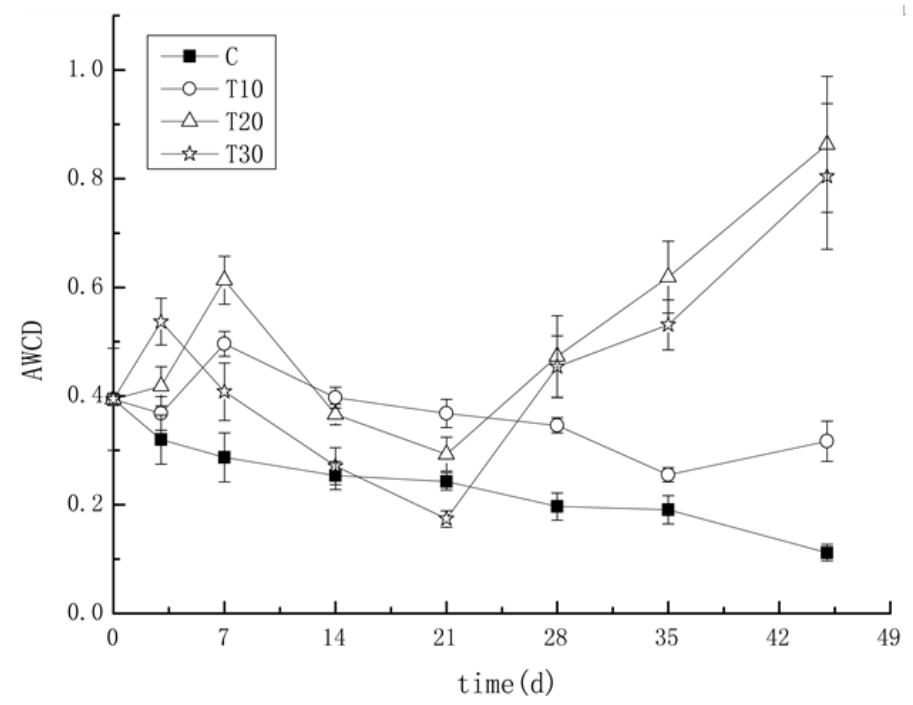

Figure 1. AWCD values of mudflat samples collected at different times after incubating for 96 h. C indicates the control group without nereids; T10, T20, and T30 indicate treatment samples with different densities of nereids (10,20, and 30 individuals per box, respectively). Error bars indicate the standard deviation of the means $(n=3)$

\section{Carbon source utilization profile of mudflat sediment microbial communities}

There are 31 single carbon sources and one blank control with three repeats distributed on the Biolog ECO microplate. The 31 carbon substrates can be roughly divided into six substrate categories (Preston-Mafham et al., 2002), which are 9 carboxylic acids, 7 carbohydrates, 6 amino acids, 4 polymers, 2 amines, and 3 miscellaneous. The relative carbon source utilization ratios were determined via the AWCD at $96 \mathrm{~h}$ incubation, and the categorized substrate utilization patterns by microbial communities are shown in Fig. 2. Overall, the utilization of microbial communities for carbohydrates, amino acids, and polymers were higher, while those for carboxylic acids, amines, and miscellaneous were lower. Further analysis indicated that, except for samples collected at $28 \mathrm{~d}$ and $35 \mathrm{~d}$, the microbial utilization for carbohydrates of all treatment samples with nereids were significantly higher than those of control samples ( $\mathrm{p}<0.05$, Table S2). However, the polymer utilization of all treatment samples was significantly lower than that of control samples ( $\mathrm{p}<0.05$, Table S3). Furthermore, the microbial utilization of amino acids of most of the treatment samples was significantly higher than that of control samples ( $\mathrm{p}<0.05$, Table S4). These results suggest that nereid bioturbation stimulated microbial utilization of carbohydrates and amino acids, but decreased the microbial utilization of polymers. In the process of the experiment, the microbial utilization of amines in control samples increased with time, while in the treatment group, the utilization for amines was not consistent among samples with different nereid density (Fig. 2, Table S5). The microbial utilization for carboxylic acids and miscellaneous also increased slightly during 
the experiment; however, the microorganisms utilizing carboxylic acids and miscellaneous were not abundant, and the nereid bioturbation effects on the microbial utilization for these substrates differed at different sampling times (Fig. 2, Table S6, Table S7).
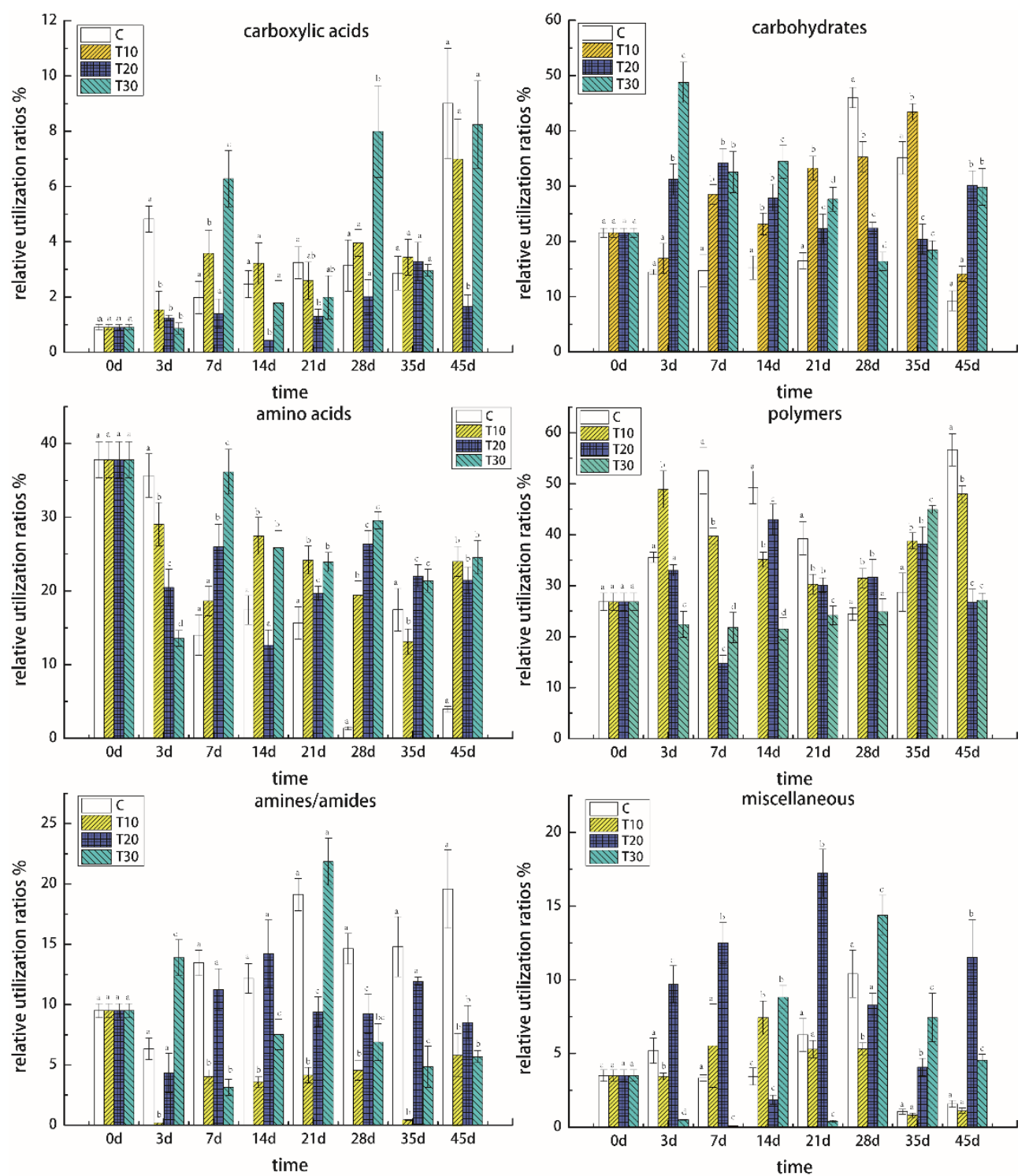

Figure 2. Categorized substrate utilization patterns at different sampling times by microbial communities from mudflat sediments after $96 \mathrm{~h}$ of incubation. Values indicated by a same letter are not significantly different $(P>0.05)$. Error bars indicate the standard error of the mean $(n=3)$. $C$ indicates the control group without nereids; T10, T20, and T30 indicate treatment samples with different nereid densities (10,20, and 30 individuals per box, respectively)

\section{Microbial functional diversity indices analysis}

Microbial functional diversity can be reflected via carbon source utilization diversity indices (Kong et al., 2013). The calculated diversity indices are shown in Fig. 3. In the control group without nereids, the Shannon index and Simpson index both decreased with time during the experiment, indicating a decreasing trend of microbial functional 
diversity. However, in the treatment group with nereids, all diversity indices were at high levels, and most of them were higher than those of samples collected at the beginning. This suggested that nereid bioturbation in mudflat sediments increased the microbial functional diversity. Compared to control samples collected at the same day, all nereid bioturbated samples had higher diversity indices, except for T30 samples collected at $14 \mathrm{~d}$ and $21 \mathrm{~d}$. Furthermore, during the later period of the experiment (after $28 \mathrm{~d}$ ), the differences between control and treatment samples reached significant levels $(\mathrm{P}<0.05$, Table S8, Table S9). Considering the effects of different nereid density, the microbial functional diversity ranked in the following order: T20 > T30 > T10, suggesting that nereid density was not simply positively correlated with microbial functional diversity, but a higher nereid density seemed to increase microbial diversity. The above variations were similar to those of microbial activity. As for the Pielou index, no obvious change trend was present after introducing nereids to the sediments, and most of the differences of the Pielou evenness indices between control and treatment groups did not reach significant levels ( $\mathrm{p}>0.05$, Table S10).
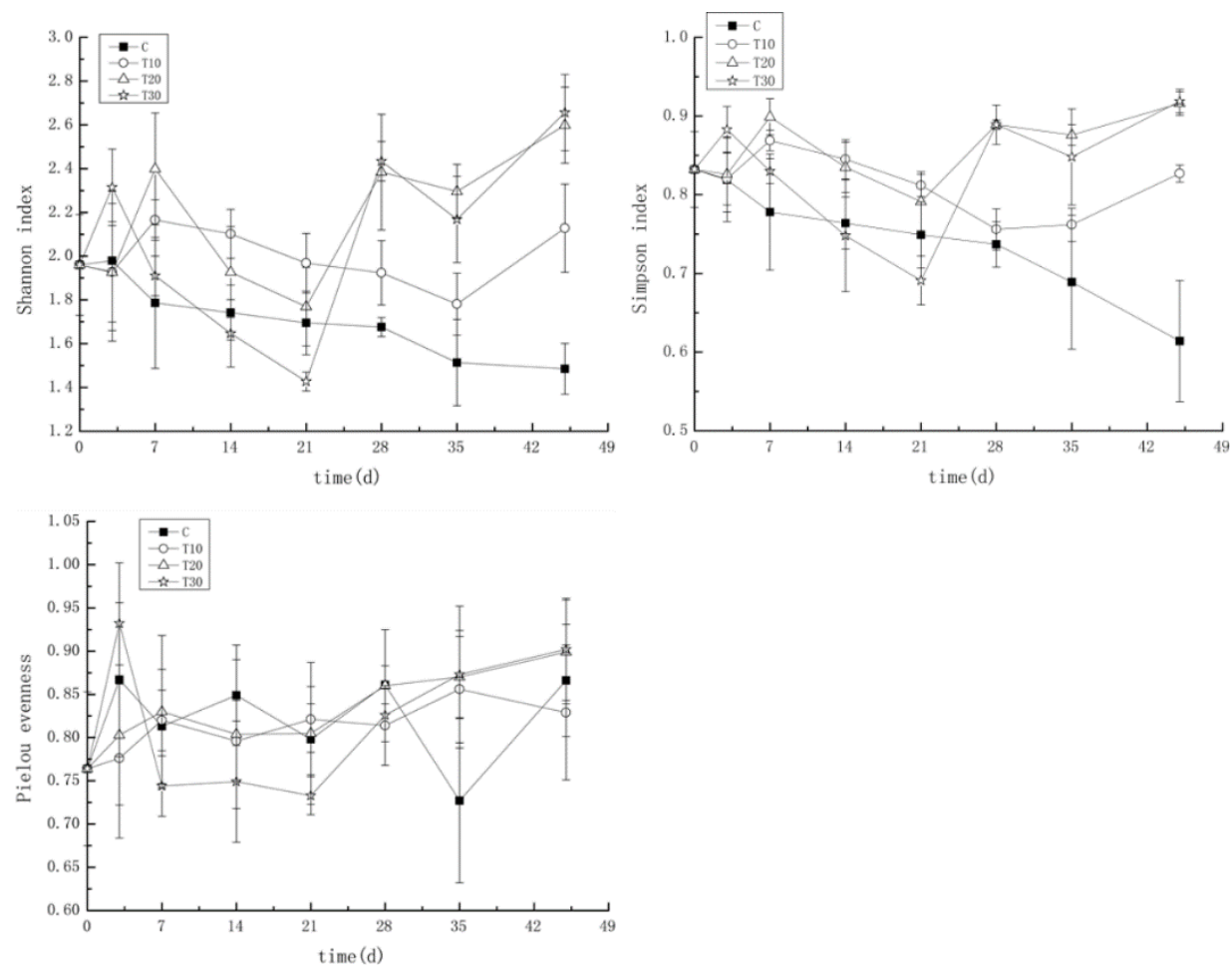

Figure 3. Carbon source utilization diversity indices of microbial communities in mudflat sediments. C indicates control group without nereids; T10, T20, and T30 indicate treatment samples with different nereid densities (10,20, and 30 individuals per box, respectively)

\section{Relationship of carbon source utilization patterns of microbial communities in different samples}

Principal component analysis (PCA) was used to determine the degree of differentiation in carbon source metabolization between treatments and control, and the results are shown in Fig. 4. PC1 and PC2, representing the first and the second principal component, explained $46.7 \%$ and $14.8 \%$ of data variance, respectively. Fig. 4 shows that the control samples without nereids (C-, shown by open circles) and the treatment samples 
collected before nereid sowing (T0, labeled by open square) were mainly located in the lower left part of the PCA, and separated from other treatment samples with nereids (labeled with filled circle, triangle, and diamond); only one sample (C-28d) was a little removed from them. However, many T10-samples were also located in this region, suggesting that a lower nereid density had less influence than those with higher nereid density.

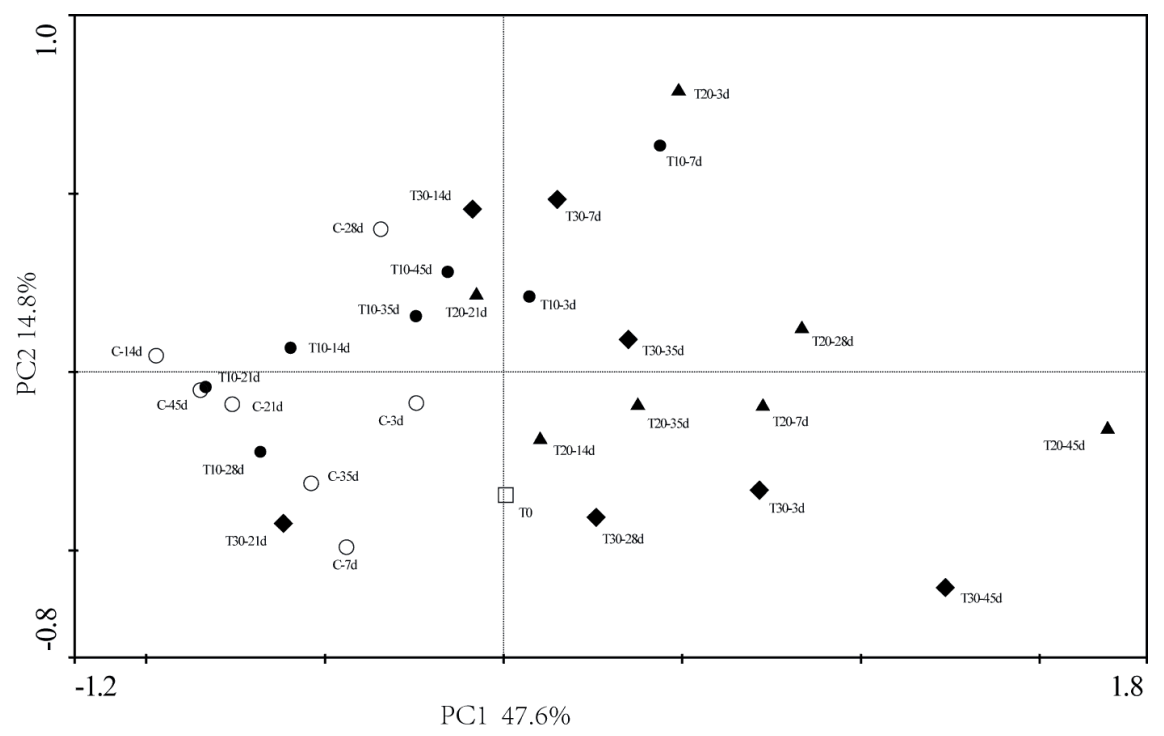

Figure 4. Principal component analysis (PCA) for microbial carbon source utilization profiles in mudflat sediments. C (open circles) indicates the control group without nereids; T10 (filled circles), T20 (filled triangles), and T30 (filled diamonds) indicate treatment samples with different densities of nereids (10,20, and 30 individuals per box, respectively). $-3 d, 7 d, 14 d$, etc. denote sampling times. TO (open square) indicates treatment sample collected before sowing nereids

\section{Discussion}

Compared to microbial community structure, microbial activities and functional diversity are more important indexes, reflecting ecological function. Biolog ECO is a fast, inexpensive, reproducible and sensitive method for detecting the activity of soil microbial communities (Islam et al., 2011; Weber and Legge, 2011; Sprocati et al., 2014; Rutgers et al., 2016). Its application has been well described on variety of research areas (Kim et al., 2017). Biolog ECO has also been used for exploring the effects of large herbivores grazing on soil microbial metabolic profiles (Qu et al., 2020), however, studies about the influence of macrobenthos bioturbation on microbial activities have never been reported.

In this study, the response of microbial activities to nereid polychaete bioturbation in intertidal mudflat sediments was investigated via the Biolog ECO method in a 45-day laboratory experiment. Results showed that the bacteria presented in the intertidal sediments prefer to utilize the easy-to-use carbon sources, such as carbohydrates, amino acids, and polymers, which were consisted with findings reported in an artificial mangrove wetland (Yin and Yan, 2020). Results also revealed that nereid bioturbation significantly improved the sediment microbial activity, and increased the carbon substrate utilization diversity. A possible reason may be that the bioturbating activities, such as migrating, feeding, excreting, and burrowing, changed sediment structure and porosity, 
loosened sediment particles and enriched dissolved oxygen in sediments (Satoh and Okabe, 2013; Boeker and Geist, 2016), thus promoting microbial metabolic activity. Previous studies reported that high levels of organics in mudflat sediments might increase the bacterial abundance and improve the bacterial degradation ability for organics (Dai and Sun, 2007), and microbial metabolic activity will be stronger when organic matter content is higher in sediments (Su et al., 2018). Nereid excrements could also be used as metabolic substrate for soil bacteria and promote bacterial growth. Previous studies indicated a higher functional diversity on the basis of carbon source utilization profiles, suggesting an improvement of soil quality (Gomez et al., 2006; Islam et al., 2011; Chaudhry et al., 2012). Nereid bioturbation increased bacterial activity and metabolic functional diversity, which might be one of the important mechanisms of bioremediation using nereids.

The influence of different nereid densities on microbial activity was different. Overall, a higher nereid density had more influence, particularly in the early and late periods of the experiment, while in the mid stage of the experiment, a lower nereid density influenced more apparently. A possible reason might be that, in the culture box with higher nereid density, some nereids died due to overcrowding and closed experiment boxes, and as these dead bodies and wastes accumulated, bioturbation and bacterial activity were inhibited. In the late period of the experiment, the decreased nereid density was beneficial for the survivals growth and activity and thus, the bacterial activity increased again.

The physicochemical characteristics in the mudflat sediments did not change significantly under nereid bioturbation (data not shown), possibly due to the short bioremediation time. Nevertheless, the response of microbial activity and metabolic functional patterns changed severely, indicating that microbial variations are more sensitive and can be used as early warnings for environmental change. Future improvements will include extending the experimental period, using larger experimental boxes, and performing field experiment as a comparison. These will enable us to better understand the response of microbial activity to nereid bioturbation. In addition, the microbial utilization of carbohydrates and amino acids increased, while that of polymers decreased after nereid introduction. However, the causes and mechanisms for such variations in carbon source utilization, and what roles these variations play in the nereid bioremediation, require further investigation. Future studies should focus on variations of functional bacteria during bioturbation, which would be benefit for illuminating the bioremediation mechanism.

\section{Conclusion}

Microbial communities in mudflat sediments are more sensitive compared to physicochemical indexes and can be used as early warnings for environmental change. After introducing nereid to mudflat sediments, the sediment microbial activity and the carbon substrate utilization diversity increased significantly. In a certain sowing range, higher sowing density of nereids showed a more enhancing influence on microbial activity. Bioturbation enhanced microbial activity for utilizing carbohydrates and amino acids, but decreased the microbial utilization of polymers. However, the results were obtained in the laboratory simulation experiment and need to be verified in the field. In addition, the relationship between the changes of sediment microbial activities and environmental factors during nereids bioturbation needs to be further studied. 
Acknowledgements. This work was supported by the National Natural Science Foundation of China (No. 31272669) and the Key Science and Technology Program of Fujian Province of China (2016N0022).

\section{REFERENCES}

[1] Banks, J. L., Ross, D. J., Keough, M. J., Macleod, C. K., Keane, J., Eyre, B. D. (2013): Influence of a burrowing, metal-tolerant polychaete on benthic metabolism, denitrification and nitrogen regeneration in contaminated estuarine sediments. - Marine Pollution Bulletin 68: 30-37.

[2] Berthet, B., Mouneyrac, C., Amiard, J. C., Amiard-Triquet, C., Berthelot, Y., Le Hen, A., Mastain, O., Rainbow, P. S., Smith, B. D. (2003): Accumulation and soluble binding of cadmium, copper, and zinc in the polychaete Hediste diversicolor from coastal sited with different trace metal bioavailabilities. - Archives Environmental Contamination Toxicology 45: 468-478.

[3] Bertics, V. J., Ziebis, W. (2009): Biodiversity of benthic microbial communities in bioturbated coastal sediments is controlled by geochemical microniches. - The ISME Journal 3: 1269-1285.

[4] Boeker, C., Geist, J. (2016): Lampreys as ecosystem engineers: burrows of Eudontomyzon sp. and their impact on physical, chemical, and microbial properties in freshwater substrates. - Hydrobiologia 777: 171-181.

[5] Booth, J. M., Fusi, M., Marasco, R., Mbobo, T., Daffonchio, D. (2019): Fiddler crab bioturbation determines consistent changes in bacterial communities across contrasting environmental conditions. - Scientific Reports 9: 3749.

[6] Chaudhry, V., Rehman, A., Mishra, A., Chauhan, P. S., Nautiyal, C. S. (2012): Changes in bacterial community structure of agricultural land due to long-term organic and chemical amendments. - Microbal Ecology 64: 450-460.

[7] Choi, K. H., Dobbs, F. C. (1999): Comparison of two kinds of Biolog microplates (GN and ECO) in their ability to distinguish among aquatic microbial communities. - Journal of Microbiological Methods 36: 203-213.

[8] Cuny, P., Miralles, G., Cornet-Barthaux, V., Acquaviva, M., Stora, G., Grossi, V., Gilbert, F. (2007): Influence of bioturbation by the polychaete Nereis diversicolor on the structure of bacterial communities in oil contaminated coastal sediments. - Marine Pollution Bulletin 54: 452-459.

[9] Dai, J. H., Sun, M. Y. (2007): Organic matter sources and their use by bacteria in the sediments of the Altamaha estuary during high and low discharge periods. - Organic Geochemistry 38: 1-15.

[10] Deng, J. S. (2006): Bioremediation effect of introducing Perineris aibuhitensis Grube and Scapharca subcrenata Lischke on shrimp pond. - Ocean University of China, Qingdao.

[11] Deng, F., Ma, Y., Li, J., Wang, Y. Z., Yan, Q. P., Yan, X. Z., Lin, M. (2015): Archaeal community structure and response to ark shell bioturbation in typical intertidal mudflats, Southeast coast of China. - Continent Shelf Research 106: 97-106.

[12] Dobranic, J. K., Zak, J. C. (1999): A microtiter plate procedure for evaluating fungal functional diversity. - Mycologia 91: 756-765.

[13] Durou, C., Mouneyrac, C., Amiard-Triquet, C. (2005): Tolerance to metals and assessment of energy reserves in the polychaete Nereis diversicolor in clean and contamined estuaries. - Environmental Toxicology 20: 23-31.

[14] Garland, J. L., Mills, A. L. (1991): Classification and characterization of heterotrophic microbial communities on basis of patterns community-level sole-carbon-source utilization. - Appllied and Environmental Microbiology 57: 2351-2359.

[15] Gomez, E., Ferreras, L., Toresani, S. (2006): Soil bacterial functional diversity as influenced by organic amendment application. - Bioresource Technology 97: 1484-1489. 
[16] Grayston, S. J., Wang, S., Campbell, C. D., Edwards, A. C. (1998): Selective influence of plant species on microbial diversity in the rhizosphere. - Soil Biology and Biochemistry 30: 369-378.

[17] Insam, H. (1997): A new set of substrates proposed for community characterization in environmental samples. - In: Insam, H., Rangger, A. (eds.) Microbial Communities. Springer-Verlag, Berlin Heidelberg.

[18] Islam, M. R., Chauhan, P. S., Kim, Y., Kim, M., Sa, T. (2011): Community level functional diversity and enzyme activities in paddy soils under different long-term fertilizer management practices. - Biology and Fertility of Soils 47: 599-604.

[19] Kim, J., Rehmann, L., Ray, M. (2017): Development of microalgal bioassay based on the community level physiological profiling (CLPP). - Algal Research 25: 47-53.

[20] Kong, X., Wang, C., Ji, M. (2013): Analysis of microbial metabolic characteristics in mesophilic and thermophilic bio-filters using Biolog plate technique. - Chemical Engineering Journal 230: 415-421.

[21] Loranger-Merciris, G., Barthes, L., Gastine, A., Leadley, P. (2006): Rapid effects of plant species diversity and identity on soil microbial communities in experimental grassland ecosystems. - Soil Biology and Biochemistry 38: 2336-2343.

[22] Ma, Y., Hu, A., Yu, C. P., Yan, Q. P., Yan, X. Z., Wang, Y. Z., Deng, F., Xiong, H. J. (2015): Response of microbial communities to bioturbation by artificially introducing macrobenthos to mudflat sediments for in situ bioremediation in a typical semi-enclosed bay, southeast China. - Marine Pollution Bulletin 94: 114-122.

[23] Marinelli, R. L., Lovell, C. R., Wakeham, S. G., Ringelberg, D. B., White, D. C. (2002): Experimental investigation of the control of bacterial community composition in macrofaunal burrows. - Marine Ecology Progress Series 35: 1-13.

[24] Murugan, R., Loges, R., Taube, F., Sradnick, A., Joergensen, R. G. (2014): Changes in soil microbial biomass and residual indices as ecological indicators of land use change in temperate permanent grassland. - Microbial Ecology 67(4): 907-918.

[25] Nautiyal, C. S., Chauhan, P. S., Bhatia, C. R. (2010): Changes in soil physico-chemical properties and microbial functional diversity due to 14 years of conversion of grassland to organic agriculture in semi-arid agroecosystem. - Soil and Tillage Research 109: 55-60.

[26] Pischedda, L., Militon, C., Gilbert, F., Cuny, P. (2011): Characterization of specificity of bacterial community structure within the burrow environment of the marine polychaete Hediste (Nereis) diversicolor. - Resarch in Microbiology 162(10): 1033-1042.

[27] Preston-Mafham, J., Boddy, L., Randerson, P. F. (2002): Analysis of microbial community functional diversity using sole-carbon-source utilisation profiles -a critique. - FEMS Microbiology Ecology 42: 1-14.

[28] Qu, T., Guo, W., Yang, C., Zhang, J., Yang, Y., Wang, D. (2020): Grazing by large herbivores improves soil microbial metabolic activity in a meadow steppe. - Grassland Science, doi: $10.1111 /$ grs.12282.

[29] Rutgers, M., Wouterse, M., Drost, S., Breure, A., Mulder, C., Stone, D., Creamer, R., Winding, A., Bloem, J. (2016): Monitoring soil bacteria with community-level physiological profiles using Biolog ${ }^{\mathrm{TM}}$ ECO-plates in the Netherlands and Europe. Applied Soil Ecology 97: 23-35.

[30] Satoh, H., Okabe, S. (2013): Spatial and temporal oxygen dynamics in macrofaunal burrows in sediments: a review of analytical tools and observational evidence. - Microbes and Environments 28: 166-179.

[31] Sprocati, A. R., Alisi, C., Tasso, F., Fiore, A., Marconi, P., Langella, F., Kothe, E. (2014): Bioprospecting at former mining sites across Europe: microbial and functional diversity in soils. - Environmental Science and Pollution Research 21: 6824-6835.

[32] Su, L., Huang, T., Li, N., Zhang, H., Wen, G., Li, Y., Chen, J., Wang, X. (2018): Characteristics of sediment oxygen demand in a drinking water reservoir. - Environmental Science 39: 1159-1166. 
[33] Sun, T., Liu, C., Li, X., An, D., Yu, H., Ma, Z., Liu, F. (2019): The effect of substrate grain size on burrowing ability and distribution characteristics of Perinereis aibuhitensis. - Acta Oceanologica Sinica 38(12): 52-58.

[34] Tian, S., Tong, Y., Hou, Y. (2019): The effect of bioturbation by polychaete Perinereis aibuhitensis on release and distribution of buried hydrocarbon pollutants in coastal muddy sediment. - Marine Pollution Bulletin 149: 110487.

[35] Tsutsumi, H., Kinoshita, K., Srithongouthai, S., Sato, A., Nagata, S., Inoue, A., Yoshioka, M., Ohwada, K., Hama, D. (2005): Treatment of the organically enriched sediment below the fish-farm with the biological activities of the artificially mass-cultured colonies of a small deposit feeding polychaete, Capitella sp. I. - Benthos Research 60: 25-38.

[36] Weber, K. P., Legge, R. L. (2011): Dynamics in the bacterial community-level physiological profiles and hydrological characteristics of constructed wetland mesocosms during start-up. - Ecological Engineering 37: 666-677.

[37] Wenzhöfer, F., Glud, R. (2004): Small-scale spatial and temporal variability in coastal benthic O2 dynamics: Effects of fauna activity. - Limnology and Oceanography 49: 14711481.

[38] Yin, Y., Yan, Z. (2020): Variations of soil bacterial diversity and metabolic function with tidal flat elevation gradient in an artificial mangrove weyland. - Science of the Total Environment 718: 137385.

\section{APPENDIX}

Supplementary Information

Table S1. Statistical analysis of the AWCD values of different sediment samples collected at the same times

\begin{tabular}{c|c|c|c|c}
\hline Sampling time & $\mathrm{C}$ & $\mathrm{T} 10$ & $\mathrm{~T} 20$ & T30 \\
\hline Od & $0.394 \pm 0.094^{\mathrm{a}}$ & $0.394 \pm 0.094^{\mathrm{a}}$ & $0.394 \pm 0.094^{\mathrm{a}}$ & $0.394 \pm 0.094^{\mathrm{a}}$ \\
3d & $0.320 \pm 0.045^{\mathrm{c}}$ & $0.368 \pm 0.031^{\mathrm{bc}}$ & $0.418 \pm 0.036^{\mathrm{b}}$ & $0.537 \pm 0.043^{\mathrm{a}}$ \\
$7 \mathrm{~d}$ & $0.287 \pm 0.045^{\mathrm{d}}$ & $0.496 \pm 0.023^{\mathrm{b}}$ & $0.613 \pm 0.044^{\mathrm{a}}$ & $0.408 \pm 0.053^{\mathrm{c}}$ \\
$14 \mathrm{~d}$ & $0.254 \pm 0.026^{\mathrm{b}}$ & $0.397 \pm 0.019^{\mathrm{a}}$ & $0.366 \pm 0.019^{\mathrm{a}}$ & $0.271 \pm 0.034^{\mathrm{b}}$ \\
$21 \mathrm{~d}$ & $0.243 \pm 0.016^{\mathrm{c}}$ & $0.368 \pm 0.026^{\mathrm{a}}$ & $0.293 \pm 0.031^{\mathrm{b}}$ & $0.174 \pm 0.015^{\mathrm{d}}$ \\
$28 \mathrm{~d}$ & $0.197 \pm 0.025^{\mathrm{c}}$ & $0.346 \pm 0.014^{\mathrm{b}}$ & $0.473 \pm 0.075^{\mathrm{a}}$ & $0.454 \pm 0.057^{\mathrm{a}}$ \\
$35 \mathrm{~d}$ & $0.191 \pm 0.026^{\mathrm{c}}$ & $0.255 \pm 0.013^{\mathrm{c}}$ & $0.619 \pm 0.066^{\mathrm{a}}$ & $0.531 \pm 0.046^{\mathrm{b}}$ \\
$45 \mathrm{~d}$ & $0.112 \pm 0.015^{\mathrm{c}}$ & $0.317 \pm 0.037^{\mathrm{b}}$ & $0.863 \pm 0.125^{\mathrm{a}}$ & $0.804 \pm 0.134^{\mathrm{a}}$ \\
\hline
\end{tabular}

Notes: $\mathrm{C}$ indicates the control group without nereids; T10, T20, and T30 indicate treatment samples with different nereid densities (10,20, and 30 individuals per box, respectively). Values are means $\pm \mathrm{SD}(\mathrm{n}=$ 3 ). Different superscript letters represent a significant difference $(p<0.05)$ between two groups at the same sampling times. The same below

Table S2. Statistical analysis of the relative utilization ratios of carbohydrates by the bacteria communities in different sediment samples collected at the same times

\begin{tabular}{c|c|c|c|c}
\hline Sampling time & C & T10 & T20 & T30 \\
\hline Od & $21.57 \pm 0.82^{\mathrm{a}}$ & $21.57 \pm 0.82^{\mathrm{a}}$ & $21.57 \pm 0.82^{\mathrm{a}}$ & $21.57 \pm 0.82^{\mathrm{a}}$ \\
$3 \mathrm{~d}$ & $14.45 \pm 0.45^{\mathrm{a}}$ & $16.91 \pm 2.73^{\mathrm{a}}$ & $31.24 \pm 2.81^{\mathrm{b}}$ & $48.77 \pm 3.64^{\mathrm{c}}$ \\
$7 \mathrm{~d}$ & $14.71 \pm 2.98^{\mathrm{a}}$ & $28.51 \pm 1.78^{\mathrm{b}}$ & $34.14 \pm 2.67^{\mathrm{b}}$ & $32.52 \pm 3.73^{\mathrm{b}}$ \\
$14 \mathrm{~d}$ & $15.26 \pm 2.12^{\mathrm{a}}$ & $23.16 \pm 1.95^{\mathrm{b}}$ & $27.91 \pm 2.45^{\mathrm{b}}$ & $34.47 \pm 3.02^{\mathrm{c}}$ \\
$21 \mathrm{~d}$ & $16.49 \pm 1.45^{\mathrm{a}}$ & $33.26 \pm 2.13^{\mathrm{b}}$ & $22.28 \pm 2.65^{\mathrm{c}}$ & $27.62 \pm 2.17^{\mathrm{d}}$ \\
$28 \mathrm{~d}$ & $46.02 \pm 1.84^{\mathrm{a}}$ & $35.27 \pm 2.79^{\mathrm{b}}$ & $22.41 \pm 1.04^{\mathrm{c}}$ & $16.37 \pm 1.68^{\mathrm{d}}$ \\
$35 \mathrm{~d}$ & $35.11 \pm 2.97^{\mathrm{a}}$ & $43.41 \pm 1.55^{\mathrm{b}}$ & $20.43 \pm 2.72^{\mathrm{c}}$ & $18.42 \pm 1.67^{\mathrm{c}}$ \\
$45 \mathrm{~d}$ & $9.24 \pm 1.81^{\mathrm{a}}$ & $14.12 \pm 1.38^{\mathrm{a}}$ & $30.09 \pm 2.69^{\mathrm{b}}$ & $29.84 \pm 3.34^{\mathrm{b}}$ \\
\hline
\end{tabular}


Table S3. Statistical analysis of the relative utilization ratios of polymers by the bacteria communities in different sediment samples collected at the same times

\begin{tabular}{c|c|c|c|c}
\hline Sampling time & C & T10 & T20 & T30 \\
\hline Od & $26.84 \pm 1.75^{\mathrm{a}}$ & $26.84 \pm 1.75^{\mathrm{a}}$ & $26.84 \pm 1.75^{\mathrm{a}}$ & $26.84 \pm 1.75^{\mathrm{a}}$ \\
$3 \mathrm{~d}$ & $35.54 \pm 0.98^{\mathrm{a}}$ & $48.87 \pm 3.61^{\mathrm{b}}$ & $33.01 \pm 1.07^{\mathrm{a}}$ & $22.40 \pm 2.57^{\mathrm{c}}$ \\
$7 \mathrm{~d}$ & $52.53 \pm 4.52^{\mathrm{a}}$ & $39.71 \pm 1.63^{\mathrm{b}}$ & $14.75 \pm 1.62^{\mathrm{c}}$ & $21.79 \pm 2.96^{\mathrm{d}}$ \\
$14 \mathrm{~d}$ & $49.25 \pm 3.21^{\mathrm{a}}$ & $35.11 \pm 1.43^{\mathrm{b}}$ & $43.01 \pm 2.98^{\mathrm{c}}$ & $21.53 \pm 2.14^{\mathrm{d}}$ \\
$21 \mathrm{~d}$ & $39.24 \pm 3.26^{\mathrm{a}}$ & $30.29 \pm 1.94^{\mathrm{b}}$ & $30.12 \pm 1.43^{\mathrm{b}}$ & $24.19 \pm 1.84^{\mathrm{c}}$ \\
$28 \mathrm{~d}$ & $24.43 \pm 1.21^{\mathrm{a}}$ & $31.47 \pm 1.87^{\mathrm{b}}$ & $31.69 \pm 3.42^{\mathrm{b}}$ & $24.89 \pm 2.55^{\mathrm{a}}$ \\
$35 \mathrm{~d}$ & $28.72 \pm 3.74^{\mathrm{a}}$ & $38.79 \pm 1.57^{\mathrm{b}}$ & $38.23 \pm 3.33^{\mathrm{b}}$ & $44.93 \pm 0.73^{\mathrm{c}}$ \\
$45 \mathrm{~d}$ & $56.62 \pm 3.12^{\mathrm{a}}$ & $47.96 \pm 1.66^{\mathrm{b}}$ & $26.74 \pm 2.58^{\mathrm{c}}$ & $27.14 \pm 1.40^{\mathrm{c}}$ \\
\hline
\end{tabular}

Table S4. Statistical analysis of the relative utilization ratios of amino acids by the bacteria communities in different sediment samples collected at the same times

\begin{tabular}{c|c|c|c|c}
\hline Sampling time & $\mathrm{C}$ & T10 & T20 & T30 \\
\hline Od & $37.81 \pm 2.45^{\mathrm{a}}$ & $37.81 \pm 2.45^{\mathrm{a}}$ & $37.81 \pm 2.45^{\mathrm{a}}$ & $37.81 \pm 2.45^{\mathrm{a}}$ \\
3d & $35.66 \pm 2.95^{\mathrm{a}}$ & $29.04 \pm 2.96^{\mathrm{b}}$ & $20.47 \pm 2.46^{\mathrm{c}}$ & $13.56 \pm 1.06^{\mathrm{d}}$ \\
$7 \mathrm{~d}$ & $14.00 \pm 2.71^{\mathrm{a}}$ & $18.62 \pm 1.98^{\mathrm{a}}$ & $25.97 \pm 3.06^{\mathrm{b}}$ & $36.17 \pm 3.04^{\mathrm{c}}$ \\
$14 \mathrm{~d}$ & $17.42 \pm 1.96^{\mathrm{a}}$ & $27.46 \pm 2.51^{\mathrm{b}}$ & $12.56 \pm 2.16^{\mathrm{a}}$ & $25.88 \pm 2.28^{\mathrm{b}}$ \\
$21 \mathrm{~d}$ & $15.64 \pm 2.19^{\mathrm{a}}$ & $24.19 \pm 1.89^{\mathrm{b}}$ & $19.65 \pm 1.02^{\mathrm{c}}$ & $23.93 \pm 1.27^{\mathrm{b}}$ \\
$28 \mathrm{~d}$ & $1.36 \pm 0.23^{\mathrm{a}}$ & $19.45 \pm 1.93^{\mathrm{b}}$ & $26.39 \pm 1.79^{\mathrm{c}}$ & $29.56 \pm 1.14^{\mathrm{c}}$ \\
$35 \mathrm{~d}$ & $17.44 \pm 2.90^{\mathrm{a}}$ & $13.08 \pm 1.75^{\mathrm{b}}$ & $22.02 \pm 1.55^{\mathrm{c}}$ & $21.40 \pm 1.55^{\mathrm{c}}$ \\
$45 \mathrm{~d}$ & $3.95 \pm 0.39^{\mathrm{a}}$ & $24.00 \pm 2.06^{\mathrm{b}}$ & $21.44 \pm 1.79^{\mathrm{b}}$ & $24.55 \pm 2.27^{\mathrm{b}}$ \\
\hline
\end{tabular}

Table S5. Statistical analysis of the relative utilization ratios of amines by the bacteria communities in different sediment samples collected at the same times

\begin{tabular}{c|c|c|c|c}
\hline Sampling time & $\mathrm{C}$ & $\mathrm{T} 10$ & $\mathrm{~T} 20$ & $\mathrm{~T} 30$ \\
\hline 0d & $9.50 \pm 0.59^{\mathrm{a}}$ & $9.50 \pm 0.59^{\mathrm{a}}$ & $9.50 \pm 0.59^{\mathrm{a}}$ & $9.50 \pm 0.59^{\mathrm{a}}$ \\
$3 \mathrm{~d}$ & $6.33 \pm 0.88^{\mathrm{a}}$ & $0.19 \pm 0.00^{\mathrm{b}}$ & $4.32 \pm 1.64^{\mathrm{a}}$ & $13.90 \pm 1.48^{\mathrm{c}}$ \\
$7 \mathrm{~d}$ & $13.46 \pm 1.06^{\mathrm{a}}$ & $4.02 \pm 0.57^{\mathrm{b}}$ & $11.24 \pm 1.74^{\mathrm{a}}$ & $3.14 \pm 0.67^{\mathrm{b}}$ \\
$14 \mathrm{~d}$ & $12.17 \pm 1.22^{\mathrm{a}}$ & $3.56 \pm 0.45^{\mathrm{b}}$ & $14.22 \pm 2.79^{\mathrm{a}}$ & $7.51 \pm 1.26^{\mathrm{c}}$ \\
$21 \mathrm{~d}$ & $19.13 \pm 1.34^{\mathrm{a}}$ & $4.15 \pm 0.64^{\mathrm{b}}$ & $9.41 \pm 1.23^{\mathrm{c}}$ & $21.86 \pm 1.95^{\mathrm{a}}$ \\
$28 \mathrm{~d}$ & $14.63 \pm 1.27^{\mathrm{a}}$ & $4.55 \pm 0.83^{\mathrm{b}}$ & $9.23 \pm 1.66^{\mathrm{c}}$ & $6.89 \pm 1.54^{\mathrm{bc}}$ \\
$35 \mathrm{~d}$ & $14.80 \pm 2.48^{\mathrm{a}}$ & $0.44 \pm 0.04^{\mathrm{b}}$ & $11.94 \pm 0.35^{\mathrm{a}}$ & $4.84 \pm 1.72^{\mathrm{c}}$ \\
$45 \mathrm{~d}$ & $19.59 \pm 3.25^{\mathrm{a}}$ & $5.79 \pm 1.78^{\mathrm{b}}$ & $8.52 \pm 1.41^{\mathrm{b}}$ & $5.68 \pm 0.49^{\mathrm{b}}$ \\
\hline
\end{tabular}

Table S6. Statistical analysis of the relative utilization ratios of carboxylic acids by the bacteria communities in different sediment samples collected at the same times

\begin{tabular}{c|c|c|c|c}
\hline Sampling time & $\mathrm{C}$ & T10 & T20 & T30 \\
\hline 0d & $0.90 \pm 0.10^{\mathrm{a}}$ & $0.90 \pm 0.10^{\mathrm{a}}$ & $0.90 \pm 0.10^{\mathrm{a}}$ & $0.90 \pm 0.10^{\mathrm{a}}$ \\
$3 \mathrm{~d}$ & $4.82 \pm 0.47^{\mathrm{a}}$ & $1.54 \pm 0.68^{\mathrm{b}}$ & $1.25 \pm 0.09^{\mathrm{b}}$ & $0.86 \pm 0.20^{\mathrm{b}}$ \\
$7 \mathrm{~d}$ & $1.98 \pm 0.58^{\mathrm{a}}$ & $3.58 \pm 0.84^{\mathrm{b}}$ & $1.40 \pm 0.53^{\mathrm{a}}$ & $6.28 \pm 1.02^{\mathrm{c}}$ \\
$14 \mathrm{~d}$ & $2.46 \pm 0.49^{\mathrm{a}}$ & $3.22 \pm 0.74^{\mathrm{a}}$ & $0.43 \pm 0.01^{\mathrm{b}}$ & $1.79 \pm 0.81^{\mathrm{a}}$ \\
$21 \mathrm{~d}$ & $3.24 \pm 0.58^{\mathrm{a}}$ & $2.59 \pm 0.67^{\mathrm{ab}}$ & $1.29 \pm 0.26^{\mathrm{b}}$ & $1.99 \pm 0.78^{\mathrm{ab}}$ \\
$28 \mathrm{~d}$ & $3.14 \pm 0.93^{\mathrm{a}}$ & $3.96 \pm 0.49^{\mathrm{a}}$ & $2.00 \pm 0.63^{\mathrm{a}}$ & $7.99 \pm 1.66^{\mathrm{b}}$ \\
$35 \mathrm{~d}$ & $2.86 \pm 0.61^{\mathrm{a}}$ & $3.44 \pm 0.65^{\mathrm{a}}$ & $3.29 \pm 0.69^{\mathrm{a}}$ & $2.96 \pm 0.21^{\mathrm{a}}$ \\
$45 \mathrm{~d}$ & $9.01 \pm 1.99^{\mathrm{a}}$ & $6.99 \pm 1.45^{\mathrm{a}}$ & $1.66 \pm 0.42^{\mathrm{b}}$ & $8.24 \pm 1.58^{\mathrm{a}}$ \\
\hline
\end{tabular}


Table S7. Statistical analysis of the relative utilization ratios of miscellaneous by the bacteria communities in different sediment samples collected at the same times

\begin{tabular}{c|c|c|c|c}
\hline Sampling time & $\mathrm{C}$ & T10 & T20 & T30 \\
\hline 0d & $3.50 \pm 0.39^{\mathrm{a}}$ & $3.50 \pm 0.39^{\mathrm{a}}$ & $3.50 \pm 0.39^{\mathrm{a}}$ & $3.50 \pm 0.39^{\mathrm{a}}$ \\
$3 \mathrm{~d}$ & $5.19 \pm 0.86^{\mathrm{a}}$ & $3.45 \pm 0.22^{\mathrm{b}}$ & $9.71 \pm 1.25^{\mathrm{c}}$ & $0.50 \pm 0.02^{\mathrm{d}}$ \\
$7 \mathrm{~d}$ & $3.34 \pm 0.22^{\mathrm{a}}$ & $5.52 \pm 2.84^{\mathrm{a}}$ & $12.49 \pm 1.39^{\mathrm{b}}$ & $0.10 \pm 0.01^{\mathrm{c}}$ \\
$14 \mathrm{~d}$ & $3.44 \pm 0.59^{\mathrm{a}}$ & $7.44 \pm 1.12^{\mathrm{b}}$ & $1.86 \pm 0.31^{\mathrm{c}}$ & $8.82 \pm 0.79^{\mathrm{b}}$ \\
$21 \mathrm{~d}$ & $6.26 \pm 1.11^{\mathrm{a}}$ & $5.29 \pm 0.59^{\mathrm{a}}$ & $17.24 \pm 1.62^{\mathrm{b}}$ & $0.39 \pm 0.09^{\mathrm{c}}$ \\
$28 \mathrm{~d}$ & $10.41 \pm 1.61^{\mathrm{a}}$ & $5.30 \pm 0.43^{\mathrm{b}}$ & $8.28 \pm 0.80^{\mathrm{a}}$ & $14.38 \pm 1.37^{\mathrm{c}}$ \\
$35 \mathrm{~d}$ & $1.05 \pm 0.17^{\mathrm{a}}$ & $0.81 \pm 0.15^{\mathrm{a}}$ & $4.08 \pm 0.59^{\mathrm{b}}$ & $7.44 \pm 1.65^{\mathrm{c}}$ \\
$45 \mathrm{~d}$ & $1.58 \pm 0.24^{\mathrm{a}}$ & $1.11 \pm 0.19^{\mathrm{a}}$ & $11.54 \pm 2.52^{\mathrm{b}}$ & $4.54 \pm 0.41^{\mathrm{c}}$ \\
\hline
\end{tabular}

Table S8. Statistical analysis of the Shannon indexes of carbon source utilizations of bacteria in different sediment samples collected at the same times

\begin{tabular}{c|c|c|c|c}
\hline Sampling time & C & T10 & T20 & T30 \\
\hline 0d & $1.960 \pm 0.230^{\mathrm{a}}$ & $1.960 \pm 0.230^{\mathrm{a}}$ & $1.960 \pm 0.230^{\mathrm{a}}$ & $1.960 \pm 0.230^{\mathrm{a}}$ \\
3d & $1.979 \pm 0.319^{\mathrm{a}}$ & $1.928 \pm 0.229^{\mathrm{a}}$ & $1.926 \pm 0.315^{\mathrm{a}}$ & $2.315 \pm 0.175^{\mathrm{a}}$ \\
$7 \mathrm{~d}$ & $1.786 \pm 0.229^{\mathrm{c}}$ & $2.165 \pm 0.092^{\mathrm{ab}}$ & $2.399 \pm 0.255^{\mathrm{a}}$ & $1.910 \pm 0.090^{\mathrm{bc}}$ \\
$14 \mathrm{~d}$ & $1.742 \pm 0.126^{\mathrm{b}}$ & $2.102 \pm 0.112^{\mathrm{a}}$ & $1.927 \pm 0.208^{\mathrm{ab}}$ & $1.647 \pm 0.154^{\mathrm{b}}$ \\
$21 \mathrm{~d}$ & $1.695 \pm 0.145^{\mathrm{b}}$ & $1.968 \pm 0.136^{\mathrm{a}}$ & $1.769 \pm 0.180^{\mathrm{ab}}$ & $1.427 \pm 0.043^{\mathrm{c}}$ \\
$28 \mathrm{~d}$ & $1.676 \pm 0.043^{\mathrm{b}}$ & $1.924 \pm 0.147^{\mathrm{b}}$ & $2.384 \pm 0.264^{\mathrm{a}}$ & $2.434 \pm 0.090^{\mathrm{a}}$ \\
$35 \mathrm{~d}$ & $1.513 \pm 0.197^{\mathrm{b}}$ & $1.781 \pm 0.142^{\mathrm{b}}$ & $2.296 \pm 0.124^{\mathrm{a}}$ & $2.168 \pm 0.197^{\mathrm{a}}$ \\
$45 \mathrm{~d}$ & $1.485 \pm 0.116^{\mathrm{c}}$ & $2.128 \pm 0.201^{\mathrm{b}}$ & $2.599 \pm 0.174^{\mathrm{a}}$ & $2.556 \pm 0.174^{\mathrm{a}}$ \\
\hline
\end{tabular}

Table S9. Statistical analysis of the Simpson indexes of carbon source utilizations of bacteria in different sediment samples collected at the same times

\begin{tabular}{c|c|c|c|c}
\hline Sampling time & $\mathrm{C}$ & $\mathrm{T} 10$ & $\mathrm{~T} 20$ & T30 \\
\hline 0d & $0.832 \pm 0.048^{\mathrm{a}}$ & $0.832 \pm 0.048^{\mathrm{a}}$ & $0.832 \pm 0.048^{\mathrm{a}}$ & $0.832 \pm 0.048^{\mathrm{a}}$ \\
$3 \mathrm{~d}$ & $0.819 \pm 0.053^{\mathrm{a}}$ & $0.820 \pm 0.033^{\mathrm{a}}$ & $0.826 \pm 0.048^{\mathrm{a}}$ & $0.883 \pm 0.029^{\mathrm{a}}$ \\
$7 \mathrm{~d}$ & $0.778 \pm 0.074^{\mathrm{b}}$ & $0.869 \pm 0.013^{\mathrm{a}}$ & $0.899 \pm 0.023^{\mathrm{a}}$ & $0.830 \pm 0.016^{\mathrm{ab}}$ \\
$14 \mathrm{~d}$ & $0.764 \pm 0.033^{\mathrm{ab}}$ & $0.845 \pm 0.025^{\mathrm{a}}$ & $0.835 \pm 0.032^{\mathrm{a}}$ & $0.748 \pm 0.071^{\mathrm{b}}$ \\
$21 \mathrm{~d}$ & $0.749 \pm 0.042^{\mathrm{ab}}$ & $0.812 \pm 0.014^{\mathrm{a}}$ & $0.791 \pm 0.038^{\mathrm{a}}$ & $0.691 \pm 0.031^{\mathrm{b}}$ \\
$28 \mathrm{~d}$ & $0.737 \pm 0.029^{\mathrm{b}}$ & $0.756 \pm 0.026^{\mathrm{b}}$ & $0.889 \pm 0.025^{\mathrm{a}}$ & $0.889 \pm 0.006^{\mathrm{a}}$ \\
$35 \mathrm{~d}$ & $0.689 \pm 0.085^{\mathrm{c}}$ & $0.762 \pm 0.021^{\mathrm{bc}}$ & $0.876 \pm 0.013^{\mathrm{a}}$ & $0.848 \pm 0.061^{\mathrm{ab}}$ \\
$45 \mathrm{~d}$ & $0.614 \pm 0.077^{\mathrm{c}}$ & $0.827 \pm 0.011^{\mathrm{b}}$ & $0.916 \pm 0.015^{\mathrm{a}}$ & $0.919 \pm 0.015^{\mathrm{a}}$ \\
\hline
\end{tabular}

Table S10. Statistical analysis of the Pielou evenness indexes of carbon source utilizations of bacteria in different sediment samples collected at the same times

\begin{tabular}{c|c|c|c|c}
\hline Sampling time & C & T10 & T20 & T30 \\
\hline 0d & $0.764 \pm 0.044^{\mathrm{a}}$ & $0.764 \pm 0.044^{\mathrm{a}}$ & $0.764 \pm 0.044^{\mathrm{a}}$ & $0.764 \pm 0.044^{\mathrm{a}}$ \\
3d & $0.867 \pm 0.049^{\mathrm{b}}$ & $0.776 \pm 0.032^{\mathrm{c}}$ & $0.803 \pm 0.031^{\mathrm{c}}$ & $0.932 \pm 0.011^{\mathrm{a}}$ \\
$7 \mathrm{~d}$ & $0.813 \pm 0.066^{\mathrm{a}}$ & $0.820 \pm 0.035^{\mathrm{a}}$ & $0.830 \pm 0.038^{\mathrm{a}}$ & $0.744 \pm 0.035^{\mathrm{a}}$ \\
$14 \mathrm{~d}$ & $0.849 \pm 0.058^{\mathrm{a}}$ & $0.796 \pm 0.047^{\mathrm{ab}}$ & $0.804 \pm 0.036^{\mathrm{ab}}$ & $0.749 \pm 0.027^{\mathrm{b}}$ \\
$21 \mathrm{~d}$ & $0.798 \pm 0.041^{\mathrm{a}}$ & $0.821 \pm 0.038^{\mathrm{a}}$ & $0.805 \pm 0.032^{\mathrm{a}}$ & $0.733 \pm 0.022^{\mathrm{b}}$ \\
$28 \mathrm{~d}$ & $0.861 \pm 0.022^{\mathrm{a}}$ & $0.814 \pm 0.046^{\mathrm{a}}$ & $0.860 \pm 0.025^{\mathrm{a}}$ & $0.826 \pm 0.031^{\mathrm{a}}$ \\
$35 \mathrm{~d}$ & $0.727 \pm 0.035^{\mathrm{b}}$ & $0.856 \pm 0.028^{\mathrm{a}}$ & $0.870 \pm 0.047^{\mathrm{a}}$ & $0.873 \pm 0.019^{\mathrm{a}}$ \\
$45 \mathrm{~d}$ & $0.866 \pm 0.065^{\mathrm{a}}$ & $0.829 \pm 0.048^{\mathrm{a}}$ & $0.899 \pm 0.010^{\mathrm{a}}$ & $0.902 \pm 0.029^{\mathrm{a}}$ \\
\hline
\end{tabular}

